\title{
Study on the Construction of Practical Teaching Base in Application Oriented University
}

\author{
Dong Liu \\ Institute of Information Science and Technology South China Business College Guangdong \\ University of Foreign Studies, Guangdong, Guangzhou 510545, China.
}

78972493@qq.com

\section{Keywords: Applied, Practical Teaching Base, Explore.}

\begin{abstract}
The construction of practice training base plays an important role in the process of personnel in Colleges and universities, the development of practical teaching base relatively stable teaching practice can not only solve the place itself, is also an important way to cultivate technology talents. This paper analyzes the problems existing in practice teaching base construction and operation mode, the paper discussed the effective way of school enterprise cooperation and remarkable achievements, lay the foundation for the cultivation of applied technical talents.
\end{abstract}

\section{Introduction}

Practice teaching base is an important place of practice teaching in Colleges and universities, is an important position of cultivating practical talents ${ }^{[1]}$. In application-oriented universities, practical teaching bases are endowed with innovative significance. Strengthening the construction of practical teaching base is an important measure to strengthen the practice of teaching, is an important part of promoting education and improve the quality of teaching. Practice teaching is important for students to understand and contact window of social production practice, it is not only to provide students with internship places and opportunities to participate in social practice, to stimulate the consciousness of innovation, but also provide teachers with teaching material, also for the professional curriculum knowledge supplement and update may provide rich, professional courses System ${ }^{[2]}$.

\section{Analysis of The Current Situation of Practice Teaching Base Construction}

(1) The number of practical teaching bases, most of the base construction form, and not in the students' practice, play a substantive role in the training of practical teaching base in Colleges and universities. Its construction is mainly on the practice base, many colleges and universities are expanding the basis of professional laboratory laboratory. These base general investment, and most have no extra income.

(2) Practice teaching content and production practice, practice form stiff because of ingrained traditional teaching concepts, teaching practice lags behind the theoretical teaching, the theoretical teaching and practical teaching conflict, often at the expense of practical teaching results for ${ }^{[3]}$. Now our school 2017 grade talent training program has been revised to improve the credit practice teaching proportion. But the construction of practical teaching system has failed to keep pace. In the graduation internship arrangements, due to time constraints, the organization of teaching factors such as the complexity of the students in the enterprise learn less, the practice effect is poor.

(3) The mechanism of the practical teaching base is not perfect, rely on personal relations phenomenon of university enterprise cooperation to establish the practical teaching base is still prevalent, poor stability of the practical teaching base, and cannot effectively ensure the stable and efficient practice base for the school practice teaching service.

(4) The "Double Teachers" lack of young teachers' lack of practical experience, no enterprise engineering background, coupled with the heavy task of teaching, it is difficult for students to practice effective guidance, to effectively carry out the practice teaching has become a "bottleneck". At present, most of the new evaluation index of local high school old university title evaluation copy the 
widespread phenomenon of teaching scientific research, take practical teaching task is low, and there is no clear calculation standard in the teaching workload and remuneration, and teachers should take students in practice in the process of transportation, production safety responsibility, so many teachers tend to be more time And energy for scientific research, unwilling to take students to base practice

\section{Practice Construction of Practice Teaching Base}

(1)Construct the practical teaching system of applied talents, to further deepen the reform of practice teaching, improve the teaching effect. The reform of teaching system must have the effectiveness and pertinence of different disciplines, different professional requirements of the practice teaching, through the teaching practice of adjusting the percentage in total credits, updating the teaching contents, improving practice teaching methods, practice plan means flexible adjustment, the construction of practice teaching system to adapt to the target of talent cultivation and application, improve the level of practice teaching of ${ }^{[4]}$.

(2)In order to attract students to participate in the project in the form of enterprises, the main form of teaching organization is completed on the basis of cooperation to build a base of practice teaching. Students to participate in school teachers and senior engineer of research and innovation base project, cultivating and training students' innovation consciousness, practical skills and research ability. Practice teaching base is also available from enterprises in the selection of talent, truly realize the "win-win".

(3)Strengthen the training of teachers, the construction of a rich experience, reasonable structure, practice teaching team with strong sense of responsibility, but also pay attention to the introduction of advanced professional talents with the enterprise background, improving the knowledge structure of teachers; regularly invited technical experts lectures, open lectures, through lectures, forums, students keep abreast of the latest technology development related technical field, is relying on the university to build a base of practice teaching is another main teaching organization. In recent years, the practice teaching base opened many lectures at high level in our hospital, and teaches advanced database technology, network operating system courses, and students in the Achieve better results.

(4)To carry out cooperation in the academic competition, practice teaching base construction should focus on the needs of the enterprise, into the system of practice teaching. Students Contest College and Hangzhou turtle Technology Co. Ltd., international and domestic well-known enterprise cooperation Guangzhou Star Group Limited, practice teaching base, carry out various cooperation of discipline competition in the campus. The competition by the United out of enterprises and schools, the school teacher and the enterprise engineering and technical personnel to participate in the guidance for students and competition awards; theme design contest have been fully demonstrated, is closely integrated with the enterprise $\mathrm{R} \& \mathrm{D}$ and production practice, and closely integrated with the training requirements for the students. In this way, the enthusiasm of students to participate in is very high, and the participation is wide, and the purpose of fostering students' engineering ability and innovative ability by subject competition is achieved.

\section{The Innovative Significance of Practice Teaching Base Construction}

\subsection{To open up new channels for the integration of production and education}

The integration of production and education become the development of China's higher education connotation development, transformation and development, and education integration usually refers to the integration of production and education cooperation in the development of the basic way of producing ${ }^{[5]}$., teaching in the production environment, production in the process of teaching, and teaching and practice. The production is closely related to the teaching base is a bridge connecting each other so. In the process of the construction of practice teaching base, should be integrated into the dominant industry, accelerate the optimization of specialty structure, make the market and campus without decoupling. The school personnel training mode and enterprise job demand to match the ${ }^{[6]}$, from the breadth and depth of effectively promoting the development of the integration of production and education. 


\subsection{A New Way to Speed Up The "Double Teachers" Training}

The "Double Teachers" is an important basis for the cultivation of applied talents, but the "double" teachers' lack of effective training mechanism and implementation path, which seriously affects the quality of applied talents. The construction of practical teaching base depth of integration between University and enterprise cooperation, this way will to further promote the two sides in the talent, technology and other aspects of resource sharing, to establish an effective "Double Teachers" training mechanism.

\subsection{The New Platform to Create Students' Innovation and Entrepreneurship}

Practice teaching base construction in cultivating applied talents and improve students' practical ability plays a positive role in cultivating students' innovation consciousness training, entrepreneurial ability cannot be replaced. The practice teaching base is an important carrier of talent cultivation, more is an important place for ${ }^{[7]}$. based on the practice teaching base of entrepreneurial innovation incubator the talent high school, guide the students to actively participate in the enterprise project, efforts to practice teaching base construction and college students' innovation ability.

\section{Conclusion}

Practice teaching base construction is a system engineering, need to constantly explore and practice between the two sides. The construction of practice teaching base of Applied Talents in Colleges and universities, to cultivate students' comprehensive quality and innovation ability and practice ability as the key point, through the establishment of the University as the main body, combined with scientific research and production closely, relying on the base to carry out multi-mode, multi-level, collaborative practice teaching work style, improve the quality of talent training with continuous efforts.

\section{Acknowledgments}

2016 South China Business College Guangdong University of Foreign Studies Project quality engineering practice teaching base in Hangzhou turtle Technology Co. Ltd. teaching base.

\section{References}

[1]. Zeng Yan. Status and development of laboratory accreditation in Universities [J]. China modern educational equipment, 2012 (17): 26-28.

[2]. Yang Cuntian. Seize the key and improve the level of government procurement. [J]. experimental technology and management, 2005229 (22): 126-129.

[3]. The history of the joint. To strengthen the construction of practice base, improve the teaching quality of [J]. Experimental technology and management, 2010, 27 (8): 190-192.

[4]. Shen Qi, Zhang Yan, Luo Yang. Construction and reform of practical teaching system of applied undergraduate course [J]. Experimental technology and management, 2010, 27(10):36-38.

[5]. Liu Yourong, Wang Jiancheng. A Guie, teaching integration mode and its influencing factors of [J]. Chinese produced higher education research in Applied Undergraduate College, 2015 (5): 64-68.

[6]. Feng Jianye, Yan Xiliang. The integration of production and education of local colleges and Universities under the cultivation of applied talents of $[\mathrm{J}]$. Chinese University of science and technology, 2016 (5):64-68.

[7]. Liu Dong, Wang Qiuping, Sun Nan, et al. Study on [J]. and economic research guide practice of cooperative teaching plan to cultivate high-quality innovative talents, 2008 (6): 204-205. 